\title{
Sex-related difference in susceptibility to cypress mortality in Austrocedrus chilensis from Northwestern Patagonia (Argentina)
}

\author{
Susceptibilidad diferencial al mal del ciprés entre sexos de Austrocedrus chilensis \\ en la Patagonia (Argentina)
}

\author{
Verónica A El Mujtar a,c*, Marcelo H Perdomo b, Leonardo A Gallo c, Oscar Grau a \\ *Corresponding author: ${ }^{a}$ Universidad Nacional de La Plata, Facultad de Ciencias Exactas de La Plata, CCT CONICET La Plata, \\ Instituto de Biotecnología y Biología Molecular (IBBM), La Plata, Argentina, velmuj@gmail.com

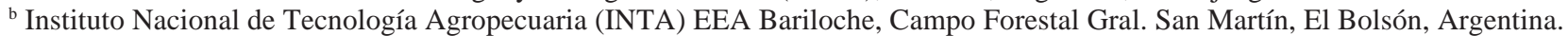 \\ ' Instituto Nacional de Tecnología Agropecuaria (INTA) EEA Bariloche, Unidad de Genética Ecológica y Mejoramiento Forestal, \\ Modesta Victoria 4450 (8400), tel.: (54)-294-4422731, San Carlos de Bariloche, Argentina.
}

\section{SUMMARY}

Female and male individuals of dioecious species have different reproductive functions and sex-related differences have been reported in growth rate, age at maturity, size, spatial distribution and physiological responses to biotic and abiotic stress. Austrocedrus chilensis (ciprés de la cordillera) is a dioecious conifer native to Patagonian Temperate Forests. Austrocedrus chilensis forests in Argentina are seriously affected by cypress mortality which has been related to drought events and biotic agents. Sex-related differences in age at maturity, reproductive cost and their mitigation, that could influence the responses to cypress mortality, have been reported for A. chilensis. However, until now no study has been conducted to evaluate sex-related differences in the susceptibility of $A$. chilensis trees to cypress mortality. In this work we detected a higher proportion of female individuals among trees affected by cypress mortality than that detected among symptomless trees. Our results suggest that cypress mortality could determine not only sex ratio bias but also changes in reproductive dynamics in A. chilensis forests.

Key words: cypress mortality, water stress, sex ratio.

\section{RESUMEN}

Los individuos femeninos y masculinos de especies dioicas tienen funciones reproductivas específicas y diferencias relacionadas al sexo han sido establecidas para la tasa de crecimiento, la edad de madurez, el tamaño, la distribución espacial y las respuestas fisiológicas al estrés biótico o abiótico. Austrocedrus chilensis (ciprés de la cordillera) es una conífera dioica nativa de los bosques templados patagónicos. En Argentina, los bosques de A. chilensis son seriamente afectados por el mal del ciprés, una mortalidad compleja que ha sido relacionada a eventos de sequía y agentes bióticos. Diferencias relacionadas al sexo en edad de madurez, costo reproductivo y sus mecanismos de mitigación, que podrían influir la respuesta al mal del ciprés, han sido reportados para A. chilensis. Sin embargo, la susceptibilidad diferencial al mal del ciprés entre sexos no ha sido previamente evaluada. En este trabajo se detectó mayor proporción de individuos femeninos entre los árboles afectados por mal del ciprés que entre los árboles asintomáticos. Los resultados sugieren que el mal del ciprés podría determinar no solo un desvío en la relación de sexos sino también cambios en la dinámica de reproducción de los bosques de A. chilensis.

Palabras clave: mal del ciprés, estrés hídrico, relación de sexos.

\section{INTRODUCTION}

Female and male individuals of dioecious species have different reproductive functions and differences could, therefore, be expected in resource allocation and physiological responses to biotic and abiotic stress. Sex-related differences in growth rate, age, size and spatial distribution have been reported (Garcia and Antor 1995, Nuñez et al. 2008). Intersexual differences in phenology and damage by herbivores and pathogens have also been evaluated, showing that the reproductive roles of females and males constrain the evolution of defense against biotic agents (Ågren 1987). In addition, secondary sexual dimorphism has been proved through the study of arbuscular mycorrhizal interactions and phenology (Vega-Frutis and Guevara 2009). With respect to abiotic stress, sex-specific responses to drought and temperature have been reported (Xu et al. 2008).

Austrocedrus chilensis (D. Don) Pic. Ser. et Bizarri (ciprés de la cordillera) is a dioecious conifer native to the temperate forests of Northwestern Patagonia in Argentina. Dissimilar results have been reported for sex-related differences in the maturity age of A. chilensis. Rovere 
(2000) determined a similar maturity age for females and males (15-20 years), whereas Grosfeld (2002) indicated differences between sexes (20-35 years for females and 45 years for males). Reproductive cost varies between sexes in A. chilensis: female trees have higher reproductive investment in terms of biomass and nutrients than do male trees, and differences vary according to site. In xeric sites females invest 4-5 times more biomass in reproduction than males, and 20-25 times more in mesic sites (Rovere 2000). Two compensation strategies of high reproductive cost for females have been reported: a) the photosynthetic capacity of female reproductive structures (Nuñez and Rovere 2005) and b) sex-related spatial distribution (Nuñez et al. 2008). Female reproductive structures are photosynthetic but they have lower values of net photosynthesis and higher values of stomatic conductance than those presented by leaves (Nuñez and Rovere 2005). Cones have stomata that are not sunken and lack the thick wax coatings of foliar stomata (Nuñez et al. 2008). Green female cones become fully developed during summer months, representing net carbon sinks and important water-loss structures where moisture is limited (Nuñez et al. 2008). These characteristics suggest that females mitigate the higher reproductive cost by means of photosynthesis of female structures, but at expenses of an increase in water loss. Moreover, sex-related spatial segregation has been shown, as males are more abundant on high-radiation slopes (sex ratio, $\mathrm{M}: \mathrm{F} \approx 1.7)$ and females more abundant on low-radiation slopes ( $\mathrm{M}: \mathrm{F} \approx 0.6$ ). This pattern was consistent and equally strong in mesic and xeric sites along a steep rainfall gradient (Nuñez et al. 2008).

Austrocedrus chilensis forests in Argentina are seriously affected by “mal del ciprés” (cypress mortality), a complex mortality process that impacts their dynamics and management strategies (Amoroso et al. 2012). Cypress mortality was initially described as a progressive withering and defoliation process, accompanied by yellowing and root rot, leading to tree death (Varsavsky et al. 1975). Based on the report by Havrylenko et al. (1989), symptoms are classified into three different groups: aboveground (or crown), underground (or root) and general symptoms such as resination, seed production and fructification. Withering, altered foliage color and defoliation are the principal aboveground symptoms, and they provide the first evidence of the onset of cypress mortality in A. chilensis forests. Changes reported in foliage color are yellowing, decoloration and chlorosis; browning is mentioned as occurring subsequent to yellowing and preceding defoliation. Red foliage is a more recent reported aboveground symptom, it has been employed to describe change color related to sudden dead (Filip and Rosso 1999, Hennon and Rajchenberg 2000) that could be or not associated to defoliation (Floria 2008). Root rot, root decay and necrotic lesions are the principal underground symptoms. Rot and necrotic lesions could be observed on the collar root; however, they are always a consequence of initial root affection. Brown rot and white fibrilar rot have been reported, isolated or simultaneously, affecting sapwood and hardwood of A. chilensis (Barroetaveña and Rajchenberg 1996). Root decay corresponds to loss of vital characteristics of tissues, but generally it is reported without a clear description and as preceding rot development. Necrotic lesions have been reported later than root rot (Rosso et al. 1994) and associated to sudden death of trees (Hennon and Rajchenberg 2000). In the last years, the high frequency of necrotic lesions reports has corresponded to the isolation of their causal agent, a new species of Phytophthora (Greslebin et al. 2010). Radial growth decline of symptomatic trees was documented as preceding crown symptoms and their onset related to warm-dry periods (Mundo et al. 2010). Fructification and resination are two generally reported symptoms; they are scarcely mentioned and not always accepted as symptoms of cypress mortality (Havrylenko et al. 1989). Recently, two types of resination have been described, located and diffuse; and local resination was associated with presence of necrotic lesions of P. austrocedrae (Floria 2008).

Several etiological models have been proposed along time to explain cypress mortality considering biotic, abiotic or a combination of both factors (El Mujtar 2009). In the last years cypress mortality has been described as: i) caused by Phytophthora austrocedrae (Greslebin and Hansen 2010) and ii) caused by differential individual susceptibility to cavitation and related to drought (El Mujtar 2009, Mundo et al. 2010). However, the etiology of cypress mortality is still a topic of discussion.

Sex-related differences in age at maturity, reproductive cost and their mitigation reported for A. chilensis could influence the responses to biotic and abiotic stress. Although cypress mortality has been related to drought events and biotic agents, until now no study has been conducted to evaluate sex-related differences in the susceptibility of A. chilensis trees to cypress mortality. The goal of this work, then, was to determine and compare the proportion of female and male individuals in symptomatic and symptomless tree groups.

\section{METHODS}

Study area. Austrocedrus chilensis forests affected by cypress mortality were sampled along the north-south oriented intermountain valley near the town of El Bolsón ( $41^{\circ} 57^{\prime} 01^{\prime \prime}$ S, $71^{\circ} 31^{\prime} 54^{\prime \prime}$ W), Río Negro province, Argentina. The study area covered 2,542 ha of mesic forests within one of the most important areas of continuous A. chilensis forests in Río Negro province.

Sanitary condition. The sanitary condition of each tree was determined according to the presence and quantification of classical aboveground symptoms (table 1). As the decline in radial growth could precede the development of external symptoms by several years, trees without aboveground symptoms of cypress mortality within affected 
Table 1. Classification of sanitary condition.

Clasificación de la condición sanitaria.

\begin{tabular}{lccc}
\hline \multicolumn{1}{c}{ Sanitary state } & Crown & Defoliation & Foliage color \\
\hline Symptomless & closed or slightly opened & without defoliation & Green \\
Symptomatic & opened with defoliation in central cone & $\geq 25 \%$ (up to 99 \%) & green pale or yellowing \\
\hline
\end{tabular}

forests cannot be classified as healthy trees. Therefore, these trees were classified as symptomless. Dead trees were not sampled because of the difficulty in determining their sex and the cause of death. Trees with red foliage were not sampled because, as mentioned before, this symptom has been associated with sudden death (Fillip and Rosso 1999, Hennon and Rajchenberg 2000); it contrasts with the classical and progressive symptoms of "mal del ciprés", and also because their frequency is lower than classical aerial symptoms in the studied stands.

Proportion of female and male individuals within symptomatic and symptomless tree groups. Two approaches were used to establish the sex ratio in symptomatic and symptomless tree groups. Firstly, fifty matched-pair case-control (symptomatic-symptomless) trees were selected between October 2006 and April 2007 from the mesic A. chilensis forest affected by cypress mortality located in the National Forest Reserve of El Bolsón, Río Negro province, Argentina. The individuals of each pair were similar in diameter at breast height, total height, crown-class position, and microsite conditions (El Mujtar 2009). The average distance between trees for each pair was less than $15 \mathrm{~m}$ (El Mujtar 2009). This sampling strategy allows selection of trees with similar crown characteristics and more clearly discriminated cypress mortality symptoms (table 1), and also provides a minimum of variability in non-analyzed factors such as soil type, water availability and climate. These fifty matched-pair case-control trees were previously characterized using dendrochronological tools (Mundo et al. 2010). Based on the interannual variations in radial growth, the applied sampling strategy was validated using a discriminant analysis. The selected individuals were clearly separated into two groups with an overall classification accuracy of $97.7 \%$ (Mundo et al. 2010). Only two symptomless trees were assigned to the symptomatic groups, the rest were correctly classified and represent healthy trees. All symptomatic trees were correctly classified. The sex was assigned by visual observation of reproductive structures for each of the matched-pair case-control trees. Reproductive structures were not observed for 10 trees, seven symptomatic and three symptomless. These trees were discarded resulting, therefore, a total of 43 symptomatic trees and 47 symptomless trees for the analysis.

In the second approach, plots of $10 \mathrm{~m}$ radius were established, centered on each of the 100 individuals selected by means of matched-pair strategy. All trees within each plot with evident reproductive structures were counted and then classified as symptomatic or symptomless trees. Considering the average distance between trees of matchedpair strategy and the size of each plot, when a tree was present in two plots it was only counted in one of them. The distribution of the sexes between symptomatic and symptomless tree groups was determined for the total number of trees, taking into account the 100 plots.

For both approaches, Fisher tests were used to evaluate differences in sex distribution between symptomatic and symptomless tree groups.

\section{RESULTS}

Proportion of female and male individuals within symptomatic and symptomless tree groups. Reproductive structures were observed for 90 individuals of matched-pair case-control trees resulting in 45 females ( $\mathrm{F}$ ) and 45 males $(\mathrm{M})$. An equilibrated sex ratio ( $\mathrm{M}: \mathrm{F}=1)$ was found for the total number of trees; however, sex distribution showed significant differences between groups in Fisher test (table 2). Considering this result and the observed values, the alternative hypothesis that females are more frequent, within the symptomatic tree group, than males was tested and accepted applying one-tail Fisher test (table 2). The same result was observed when the analysis was made considering healthy and symptomatic trees (unshowed data).

For the second approach similar results were obtained. Based on a total number of 464 trees, an equilibrated sex ratio ( $\mathrm{M}: \mathrm{F}=1.02)$ was established, while differences in sex distribution were determined between symptomatic and symptomless tree groups (table 2). In accordance with one-tail Fisher test, females were more frequent in the symptomatic group than males. Sex ratio bias was higher for matched-pairs than for plots (table 2).

\section{DISCUSSION}

Cypress mortality affects A. chilensis forests in Argentina. Although sex-related differences in responses to several kinds of stress have been reported for other dioecious species (Ågren 1987, Xu et al. 2008, Vega-Frutis and Guevara 2009), they had not been previously studied in relation to cypress mortality. In this work, we established that female individuals were more frequent among symptomatic trees than males, leading to the conclusion that female trees are more susceptible to cypress mortality. The deter- 
Table 2. Distribution of sexes between symptomless and symptomatic trees, determined for matched-pairs and plots. Distribución de sexos entre árboles asintomáticos y sintomáticos, determinada para pares de árboles y parcelas.

\begin{tabular}{|c|c|c|c|c|c|c|}
\hline & \multirow{2}{*}{ Number of trees } & \multirow{2}{*}{ Female } & \multirow{2}{*}{ Male } & \multirow{2}{*}{$\mathrm{M} / \mathrm{F}^{\S}$} & \multicolumn{2}{|c|}{ Fisher test ( $P$-value) } \\
\hline & & & & & exact & one-tail \\
\hline \multirow{3}{*}{ Matched-pairs } & Total & 45 & 45 & 1.00 & -- & -- \\
\hline & Symptomatic & 27 & 16 & 0.59 & \multirow{2}{*}{0.03426} & \multirow{2}{*}{0.01713} \\
\hline & Symptomless & 18 & 29 & 1.61 & & \\
\hline \multirow{3}{*}{ Plots } & Total & 230 & 234 & 1.02 & -- & -- \\
\hline & Symptomatic & 100 & 75 & 0.75 & \multirow{2}{*}{0.01275} & \multirow{2}{*}{0.00723} \\
\hline & Symptomless & 130 & 159 & 1.22 & & \\
\hline
\end{tabular}

${ }^{\S} \mathrm{M} / \mathrm{F}$ : sex ratio of male and female individuals.

mined bias in sex ratio was higher for matched-pairs than for plots. Although the plots method has a higher sample size which could explain the difference, this result probably reveals the clearer discrimination of cypress mortality symptoms when trees are selected using the strategy of matched-pairs. This strategy avoids the confusing effects of competition, crown class position and light exposition in the classification of the sanitary state of trees, especially when trees in different forest strata are compared.

Sex ratio bias has been reported for $A$. chilensis in marginal and ancient populations, although in some cases this pattern could not be related to site conditions or tree age (Rovere and Le Quesne 2005). On a landscape scale, evidence suggests that the number of females does not increase toward the moister side of the gradient in the western area, nor is there a trend of more males towards the more xeric eastern side (Rovere 2000, Nuñez et al. 2008). However, within a population, bias in the sex ratio was detected when different slopes were analyzed independently: female trees were more abundant in moister and shadier habitats, whereas male trees were more abundant on slopes with high radiation exposure (Nuñez et al. 2008). Due to the strategies used in the present work to detect sex ratio bias in symptomatic and symptomless tree groups, slope influence could be discarded because the average distance between matched-pair trees was lower than $15 \mathrm{~m}$ and slope and radiation exposure were similar. Therefore, our results suggest that the higher susceptibility of female individuals to cypress mortality affects the sex ratio of $A$. chilensis forests and that it should be considered as a possible cause when the bias of sex ratios are analyzed, because its influence can also modify the expected spatial segregation of the sexes. For example, according to Nuñez et al. (2008) in moister and shadier habitats the sex ratio (M:F) will be lower than 1 . However, if cypress mortality occurs at these sites, the higher number of female trees affected could counteract this bias. The sex ratio within a site or population will then be determined at least by changes in the intensity of both processes (spatial segregation and cy- press mortality), which can interact in the same or in the opposite direction.

For the matched-pair case-control trees used in the present work, the onset of radial growth decline was related to drought events (Mundo et al. 2010). Significant differences in growth patterns were established, with the growth of symptomatic trees consistently lower than that of symptomless trees following extreme drought events (Mundo et al. 2010). Considering the higher proportion of female than male individuals among symptomatic trees, these results suggest that females could be more susceptible to drought events than males. However, further studies dealing with sex-specific responses to drought in A. chilensis, such as ecophysiological studies and the evaluation of climate-growth relationships for both sexes, should be carried out in order to understand more fully the behavioral differences between female and male individuals of this dioecious native species of Patagonian temperate forests. The dendrochronological study of matched-pair trees also reveals larger radial growths in symptomatic than those revealed in symptomless trees during early decades before extreme drought events that correlate with the onset of radial growth decline (Mundo et al. 2010). Considering that growth has relatively low priority for resource allocation within trees (Waring and Pitman 1985) data suggest that trees affected by extreme drought events were those of the higher vigor. In other words these results do not support a contrary sequential hypothesis, namely that $P$. austrocedrae infected and weakened trees before drought events (Vélez et al. 2012). In addition, only the $44 \%$ of the symptomatic trees from matched-pairs showed lesions of $P$. austrocedrae at root collar (El Mujtar 2009) and both sexes were similarly affected ( 9 females, 9 males and 4 trees without reproductive structures).

Cypress mortality could strongly influence the regeneration process in A. chilensis forests, altering mating patterns through two general processes, sex ratio bias and modification of site conditions. Impact of cypress mortality in stand dynamics, seedling recruitment and 
species composition of regeneration in A. chilensis forests has been reported (La Manna et al. 2008, Amoroso et al. 2012). The consequences of cypress mortality in mating patterns through sex ratio bias are, however, not yet studied. Variation in genetic diversity between overstory A. chilensis trees and understory establishment also needs to be considered for future studies.

In Argentina, silvicultural practices in A. chilensis forests are constrained by cypress mortality and practically limited to the logging of dead and affected trees. Recently, the implementation of partial cuttings using the removal of low basal area proportions has been proposed as a management strategy of $A$. chilensis forests affected by cypress mortality (Amoroso and Larson 2010). Findings of our study indicate that silvicultural practices proposed for these forests need to take into account the sex ratio bias associated to cypress mortality and also consider the impact of management on the biodiversity of affected forests, which has been, still, scarcely studied.

As mentioned before, cypress mortality and its influence in stand dynamics has been related to climatic events (Mundo et al. 2010, Amoroso et al. 2012); therefore, considering the context of future climate changes that may generate drier conditions for the southern Andes (Christensen et al. 2007), special attention should be paid to the detection of new areas of cypress mortality occurrence and the evaluation of possible management strategies for the conservation of this native species that consider the higher affection of female individuals by cypress mortality.

\section{ACKNOWLEDGMENTS}

This research was supported by the Agencia Nacional de Promoción Científica y Tecnológica of Argentina (PICT 25518). The authors thank E. Andenmatten from Campo Forestal General San Martín, Instituto Nacional de Tecnología Agropecuaria (INTA) of Argentina for sampling permission in cypress stands of "Loma del Medio-Río Azul" National Forest Reserve. Thanks are also due to Audrey Urquhart for revision of the English version of this manuscript and to three anonymous reviewers for their comments.

\section{REFERENCES}

Ågren J. 1987. Intersexual differences in phenology and damage by herbivores and pathogens in dioecious Rubus chamaemorus L. Oecologia 72:161-169.

Amoroso MM, BC Larson. 2010. Can a natural experiment be used as a tool to design partial cutting regimes? The decline of Austrocedrus chilensis forests, an example. Journal of Forest Research 15 (1): 38-45.

Amoroso MM, ML Suarez, LD Daniels. 2012. Nothofagus dombeyi regeneration in declining Austrocedrus chilensis forests: Effects of overstory mortality and climatic events. Dendrochronologia 30: 105-112.

Barroetaveña C, M Rajchenberg. 1996. Hongos Aphyllophorales (Basidiomycetes) que causan pudriciones en Austrocedrus chilensis en pie. Boletín de la Sociedad Argentina de Botánica 31(3-4): 201-216.

Christensen JH, B Hewitson, A Busuioc, A Chen, X Gao, I Held, R Jones, RK Kolli, WT Kwon, R Laprise, V Magaña Rueda, L Mearns, CG Menéndez, J Räisänen, A Rinke, A Sarr, P Whetton. 2007. Regional Climate Projections. In Solomon S, D Qin, M Manning, Z Chen, M Marquis, KB Averyt, M Tignor, HL Miller, eds. Climate Change 2007: The Physical Science Basis. Contribution of Working Group I to the Fourth Assessment Report of the Intergovernmental Panel on Climate Change. NY, USA. Cambridge University Press, Cambridge, United Kingdom and New York. p. 847-940.

El Mujtar V. 2009. Análisis integrado de factores genéticos, bióticos y abióticos para la formulación de una nueva hipótesis sobre la etiología del “mal del ciprés”. Ph.D. Thesis. Buenos Aires, Argentina. Universidad Nacional de La Plata. $383 \mathrm{p}$.

Filip GM, PH Rosso. 1999. Cypress mortality (mal del ciprés) in the Patagonian Andes: comparisons with similar forest diseases and declines in North America. European Journal of Forest Pathology 29: 89-96.

Floria MP. 2008. Caracterización y evaluación de la sintomatología del Mal del Ciprés. Degree thesis. Esquel, Argentina. Universidad Nacional de la Patagonia San Juan Bosco. 52 p.

Garcia MB, RJ Antor. 1995. Age and Size Structure in Populations of a Long-Lived Dioecious Geophyte: Borderea pyrenaica (Dioscoreaceae). International Journal of Plant Sciences 156(2): 236-243.

Greslebin AG, EM Hansen. 2010. Pathogenicity of Phytophthora austrocedrae on Austrocedrus chilensis and its relation with mal del ciprés in Patagonia. Plant Pathology 59: 604-612.

Grosfeld J. 2002. Análisis de la variabilidad morfológica y arquitectural de Austrocedrus chilensis (D. Don) Pic. Serm. et Bizzarri, Fitzroya cupressoides (Molina) I. M. Johnst., Pilgerodendron uviferum (D. Don) Florin y Cupressus sempervirens L. (Cupressaceae). Ph.D. Thesis. Bariloche, Argentina. Universidad Nacional del Comahue. 314 p.

Havrylenko M, PHA Rosso, SB Fontenla. 1989. Austrocedrus chilensis: contribución al estudio de su mortalidad en Argentina. Bosque 10(1): 29-36.

Hennon PE, M Rajchenberg. 2000. El “mal del ciprés”. Algunas observaciones, comparaciones e ideas. Patagonia Forestal $\mathrm{VI}(2)$ : 4-6.

La Manna L, M Collantes, J Bava, M Rajchenberg. 2008. Seedling recruitment of Austrocedrus chilensis in relation to cattle use, microsite environmental and forest disease. Ecología Austral 18: 27-41.

Mundo IA, VA El Mujtar, MH Perdomo, LA Gallo, R Villalba, MD Barrera. 2010. Austrocedrus chilensis growth decline in relation to drought events in Northern Patagonia, Argentina. Trees 24: 561-570.

Nuñez CI, AE Rovere. 2005. Dimorfismo sexual en el Ciprés de la Cordillera. Patagonia Forestal XI(3): 5-6.

Nuñez CI, MA Nuñez, T Kitzberger. 2008. Sex-related spatial segregation and growth in a dioecious conifer along environmental gradients in northwestern Patagonia. Ecoscience 15: 73-80.

Rosso PH, N Baccalá, M Havrylenko, S Fontenla. 1994. Spatial pattern of Austrocedrus chilensis wilting and the scope of autocorrelation analysis in natural forests. Forest Ecology and Management 67: 273-279. 
Rovere A. 2000. Razón de sexos y crecimiento diferencial del ciprés de la cordillera $A$. chilensis (Cupressaceae), a lo largo de un gradiente de precipitación. Ph.D. Thesis. Bariloche, Argentina. Universidad Nacional del Comahue. 155 p.

Rovere AE, C Le Quesne. 2005. Austrocedrus chilensis: ¿Existen diferencias somáticas y demográficas a consecuencia de la dioicidad en esta conífera? In Carabelli F, G Deffossé, J Enricci, M Gobbi, A Greslebin, O Pico, M Rajchenberg eds. Actas de la I Reunión sobre ecología, conservación y uso de los bosques de ciprés de la cordillera (Esquel, Chubut). Centro de Investigación y Extensión Forestal Andino Patagónico (CIEFAP). p. 135-140.

Varsavsky E, L Bettucci, D Rodríguez García, C Gómez. 1975. Observaciones preliminares sobre la mortalidad del ciprés (Austrocedrus chilensis) en los bosques patagónicos. Bari- loche, Argentina. Fundación Patagonia 19: 1-11.

Vega-Frutis R, R Guevara. 2009. Different arbuscular mycorrhizal interactions in male and female plants of wild Carica papaya L. Plant and Soil 322: 165-176.

Vélez ML, PV Silva, OA Troncoso, AG Greslebin. 2012. Alteration of physiological parameters of Austrocedrus chilensis by the pathogen Phytophthora austrocedrae. Plant Pathology DOI: 10.1111/j.1365-3059.2011.02585.x

Waring RH, GB Pitman. 1985. Modifying lodgepole pine stands to change susceptibility to mountain pine beetle attach. Ecology 66: 889-897.

Xu X, F Yang, X Xiao, S Zhang, H Korpelainen, C Li. 2008. Sex-specific responses of Populus cathayana to drought and elevated temperatures. Plant, Cell and Environment 31: 850-860.

Recibido: 28.02.12

Aceptado: 11.06 .12 